\title{
CIVIL SERVICE REFORM IN TRANSITION: A CASE STUDY OF RUSSIA
}

Svetlana Inkina

University of Toronto

\begin{abstract}
Public administrative and civil service reforms have widely been used as a popular strategy to bring about systemic changes in entrenched bureaucracies. The general tendency that occurred in Post-Communist states was to adopt comprehensive policy measures dealing with the efficiency and effectiveness of state apparatus. This paper examines the process of an attempted civil service reform in Russia starting from the first term of Putin's Presidency. Based upon interviews with experts and senior public officials, it elaborates on the role of leadership, or the willingness of the national political elite to improve the system of public administration; the impact of path-dependency upon the course of institutional transformation; and finally, the role of reform strategy in the policy implementation process. The article concludes that the case of civil service reform in Russia may be explained by a combination of policy-making variables listed above. In addition, it highlights the transformation of the Russian policy-making system during the years of political centralization.
\end{abstract}




\section{Introduction}

At the end of the twentieth century, most post-communist societies had undergone a process of rapid political transformation, bringing about fundamental changes in scholarly approaches toward the state. Institutional reforms that swept away former communist countries at a speed unprecedented in recent history resulted in a retreat from centralized government and inspired hopes for the improvement of the quality of governance practices across the post-Communist region. Paradoxically, the majority of state efforts to rebuild public service in Central and Eastern Europe have failed to achieve their ultimate goals. ${ }^{1}$ Corruption, nepotism, and other negative consequences of post-communist transformation have flourished in the decade since the collapse of the Soviet system. Some countries, such as Russia, were driven downward on a scale of economic freedom in recent years; others improved slightly, but without any significant change in the nature of public governance.

In all stages of institutional restructuring, the implementation process was troubled by problems associated with the role of the post-Soviet heritage, as well as the strategy of reform process. Questions asked were as follows: what should be the scope and the time frame of reforms; how should it deal with the legacy of the post-Communist transformation; how does one combine top-down and bottom-up approaches in administrative change; and why do the national governments postpone public administrative reforms until nearly one decade since the collapse of Communism? Much of this debate intensified in recent years, when some of the Central and East European countries (CEECs), including Russia, demonstrated the lack of capacity to achieve any significant breakthrough in the operation of their public administration systems (Nunberg 1999).

In Russia, civil service reform (CSR) was implemented in several steps. The first step took place during the 1990s, and it was characterized by institutional inertia in the area of civil service. The majority of the Federal laws adopted during this period (The Law 'On the general principles of self-organization' (1995), the Law 'On the basic principles of the civil service in the Russian Federation' (1995), and others) were characterized by the lack of implementation measures, and they were rarely fulfilled in a systematic fashion. However, since 2003, public administrative reform (PAR), which included CSR as an essential component, has become a part of a comprehensive reform package aimed at achieving greater efficiency within the postcommunist state apparatus. In July 2004, the Federal Council passed a new law, "On Civil Service in the Russian Federation” (Federal Law no. 79), which developed various innovative approaches to the organization of Russian civil service. ${ }^{2}$ Similar to other post-communist countries, a new civil service law in Russia has become a key point of reform and its management. However, as Beblavy $(2002,58)$ points out, "it would be a mistake to treat all policy measures as a reform." Scholars observe that civil service reform in Russia has never been truly popular among regional and national bureaucrats. In this respect, the lack of improvement in terms of enhancing transformative capacities of Post-Soviet bureaucracies has yet to be explained.

1. Exceptional cases in terms of public administrative and civil service reforms included the Baltic states, as well as Polish, Hungarian and Slovak transitions (Meyer-Sahling, J. 2009).

2. For more information on the content of Civil Service Law (2004) please see Konov (2006), Kotchegura (2008) and others. 
This study elaborates on three major hypotheses, inspired by the empirical observation of the cases of Post-Communist transformation (Beblavy 2002, Krasnov 2003, Barabashev 2005, Obolonsky 2006, Kotechgura 2008, Temmes 2004, Oleinik 2009, Meyer-Sahling, 2009). ${ }^{3}$

One explanation is that the majority of administrative reform efforts were motivated politically, and therefore they have to be evaluated in a broader context of political transformation. The underlying assumption of this explanation is that at the start of the current wave of reform process, there was no genuine political will to reform, and therefore populist measures produced the discrepancy between the official goals and hidden agendas of national leaders, which resulted in the lack of reform progress.

Some scholars (Krasnov 2003; Obolonsky 2006; Gaman-Golutvina 2008; Jakobson 2010) argue that civil servants act as the main participants in the reform process; hence state bureaucracy cannot be trusted in a process that is likely to lessen its own power and privileges. An alternative hypothesis presented in my study suggests that the outcomes of civil service reform depend upon the nature of institutional design developed in Russia during the last several years. Based on the analysis of scholarly work mentioned above, it can be argued that public bureaucracy is not a uniform entity. It is split into groups with distinct transformative capacities that influence their ability to access policy-making decisions. Overall, this hypothesis may be linked to the attempt of public bureaucrats to block the process of policy implementation. At the same time, it highlights the specific organizational characteristics of the post-communist system.

Finally, there is a third hypothesis, suggesting that reform success is influenced by the content of reform strategy. The scope, timing, and sequencing issues need to be considered because of the fact that it is impossible to conduct comprehensive policy change if the conditions for this moment are not ready.

Given the fact that each of these hypotheses refers, in one way or the other, to the history of the post-Communist transformation, I have chosen the institutional approach to explain the case of civil service reform in Russia. The reason for this choice is the mechanism of path dependency that works well in explaining the cases of both policy continuity and the break with the past in public policy making process. Historical institutionalism describes institutions as "historically determined rules, norms, values and expectations that, at later historical stages, may independently affect outcomes when actors become wedged between old and new standards of behaviour" (Thelen and Steinmo 1992; Peters 1999; Nogaard 2000). The mechanism of pathdependency, in this respect, views the destiny of the transition development as preconditioned by the starting points of change (Temmes 2004). ${ }^{4}$

The study uses a variety of qualitative methodology instruments to assess the impact of key variables upon civil service reform progress in Russia. A large part of my research draws upon semi-structured interviews with senior public officials and civil service experts in Russia who were involved in a process of policy formulation and implementation during the last several decades. The sample of interviewees includes 35 experts who were referenced in major public policy reform committees, authors in academic journals, and within the circle of public policy professionals both in Canada and Russia. This study is complemented by the analysis of the federal legislation, statistical and sociological reports dealing with the process of CSR.

3. These hypotheses were developed by author, and they generate knowledge from various streams of scholarly work, rather than test the existing theories of policy-making process. For more information on the empirical foundations of my hypotheses please see the next section 'The Nature of the Reform We Are Dealing With'.

4. For more information, please see Paul Pierson (2000) and Margaret Levi (1997). 
In what follows, I observe the CSR and PAR in a historical perspective, outlining the basic stages of the reform process and the way in which Russian experience relates to the ongoing international trends. I discuss the scholarly literature on policy implementation process, and look into various explanations of reform progress in Russia, based on the empirical findings of my study (interviews with experts and public officials). At the end, I return to my hypotheses, trying to understand how useful they are in explaining the Russian case of civil service reform.

\section{The Nature of the Reform We Are Dealing With}

Administrative reform is one of the most dynamic aspects of modern states, as it deals with the core public sector, the administrative side of the government, and public management (Khan 2001). Since its introduction in 1960, administrative reform has been used as a popular strategy to bring about major changes in entrenched bureaucracies.

The wave of public administrative reforms that occurred between 1980 and the 1990s in Western European countries was guided by the ideas of the New Public Management (NPM) approach, directed toward a more flexible and efficient societal organization. Obviously, very few countries have managed to resolve all governance issues at once, even though comprehensive public policy changes were attempted nearly everywhere. Some of the technical areas of public administration reform, such as e-governance, proved to be more successful than others. However, the majority of states faced severe obstacles in tackling the problems of poor performance management, politicization of the civil service, corruption in government, and lack of trust.

Scholarly literature (Pressman and Wildawsky 1973; Matland 2005; Chakerian 2001; Shofield 2001; Sabatier 2005.) identifies several reasons for the lack of progress in CSR implementation process. One of the most obvious explanations originates in the strategic and tactical choices that policy-makers take at the stage of policy formulation (the decision-making process, the choice of policy instruments, and the strategy of reform). Another reason relates to the process of reform implementation, such as the lack of policy implementation mechanisms, the imperfections of policy assessment tools, tactical choices on behalf of policy implementers, and the behaviour of public bureaucrats. In more recent literature (Matland 2005; Chakerian 2001; Kingdon 1995) the problems of policy-making process were described as being mutually dependent. However, this idea is not new-for example, Hoppe in 1987 (582) asserted that the major problems at the stage of policy implementation emerge due to the disconnected cognitive levels and maps of reform designers, implementers, and target groups.

Explanations of policy-making progress in post-Communist states coincide greatly with some of the findings in Western liberal democracies. However, critics observe that in a transitional context, reformers tend to experiment freely with the newly available instruments of public policy, and they are more likely to come up with self-defeating reform projects that end up nowhere in terms of implementation. In this context, public administrative reforms risk impeding the operational capacities of national governments and therefore blocking some other important reform projects.

Nearly all explanations of policy-making processes in a transitional context include the structural, institutional, and voluntaristic components. For example, the majority of the empirical cases advanced by the leading policy-making institutions, such as the World Bank, or the UNDP program, emphasize the role of the strategy of reform, that is, the scope, the pace, the choice of policy instruments and policy implementers during the course of public policy change. Studies in 
the Russian scholarly literature (Barabashev 2005; Kotchegura 2008; Gaman-Golutvina 2008; Oleinik 2009) suggest that success is defined by the range of factors that vary from the model of public administration state reformers are trying to build to the process of micro-implementation, which includes setting up the goals, strategies, activities, and contacts of the actors involved. Overall, the number of explanatory variables is immense, and not all of them are clearly elaborated.

Finally, there is a growing body of literature (theories of policy diffusion process discussed in Barabashev and Straussman 2005; Zhang and Straussman 2003; DiMaggio and Powell 1991) arguing that reforms are context-bound processes, and therefore, success of reforms depends on the way in which the newly developed institutions adjust to the pre-existent conditions within each particular case. ${ }^{5}$ In this case, the choice of approach (the strategy of reform) may also need to consider the pre-existing conditions of institutional transformation (such as the heritage of post-Communism).

The choice of hypotheses of my study, presented in the first half of this paper, centers around the role of political will, institutions and the strategy of reforms, and it is based upon the scholarly analysis and discussed above. The role of reform strategy and political will to reform are more clearly elaborated in Western policy-making literature (Matland 1995; Court and Cottrell 2004; Sabatier 2005), whereas the study of institutional legacies in policy-making system of Russia is practically non-existent. It is important to note that the area of public policy change in a transitional context is continuously challenged by the fact that the field is conceptually underdeveloped. It lacks concepts to grasp the complexity of post-Communist transformation, and it does not clearly distinguish among the diverse phenomena that influence the process of policy change. My interest lies in the opportunity to elaborate on those aspects of reforms in Russia that will contribute to a better understanding of policy-making process in a transitional context.

\section{Public Administrative Reform in Post-Communist States: The Case of Russia}

The start of public administrative reform in Russia was marked by the collapse of the Soviet Union and by the first attempt on behalf of the Russian government to redefine the legal basis for the civil service system. This effort coincided with the drafting of the Constitution of the Russian Federation in 1992, which was followed by the adoption of the federal law called 'On the Basic Principles of the State Civil Service in the Russian Federation' (1995, no. 119).

In 1997-8, a group of reform-minded political advisors (Vladimir Krasnov, Georgii Satarov and other experts who had worked closely with the presidential administration), introduced the 'Draft Law on Public Administration Reform' to President Yeltsin. This document contained harsh criticisms of the post-communist state apparatus and promoted the idea of an open, meritbased civil service system. The idea of reform was welcomed by the President and served as an important ideological foundation for developing a new reform agenda. However, due to the structure of the government's priority-setting process at the time, the document has never been officially published.

In the year 2001, public administration reform became an issue of top priority on the agenda of the newly elected Russian government. Federal powers launched a set of comprehensive policy measures aiming to adjust the machinery of the state to the changing political context.

5. These theories originate within the body of developmental research. However, in recent years they found way into the studies of the post-Communist transformation (such as Barabashev 2005). 
Most of these reforms went in line with the process of political centralization, the technocratic model of public administration, hierarchy of bureaucratic organization, and centralized control. Consistently, reforms attempted to achieve greater efficiency and responsiveness in the state apparatus via the functional and managerial reorganization.

One of the crucial challenges for the Russian government at the initial stages of reform process was to devise a coherent strategy that would make civil service system more efficient and organized. Political turmoil during the 1990s created favourable conditions for the growth of informal practices that helped former nomenclature stay in its old place. Thus when reforms started, policy-makers had to deal with the legacies of post-Communist transformation, along with the overly powerful body of state bureaucrats.

The process of policy formulation involved several important actors: (1) representatives of the presidential administration, (2) ministries and agencies of the Russian government, and finally, (3) expert research community based in the leading institutions of higher education (Institute of Strategic Research under the President, The Academy of Science under the President, Higher School of Economics). Very often, political actors relied on advice from the expert research community, which included scholars and practitioners specializing in the area of public service. These groups were exposed to the ongoing debate on PAR in foreign countries, and therefore they played an important role in adjusting some of the most innovative, foreign-born ideas to the conditions of post-communist transformation.

In the framework of the Federal program for reforming the state service (2003-2005), the federal government prepared and adopted several important laws. The first one was Federal Law no. 55, 'On Public Service System in the RF' (2003), which divided the public service system into three categories: the civil service, the police service, and the military service. The next law, 'On State Civil Service of the Russian Federation' (no. 79), emerged in 2004 as a follow-up to the newly established institutional framework discussed earlier. The ultimate goal of the law no. 79 was to profoundly modernize the system of goals, rationales, and operational principles of the post-Soviet bureaucracy; this included improved systems of remuneration, career promotion, conflict of interest regulations, job descriptions, and other measures dealing with the efficiency of state apparatus.

Experts interviewed in my study agree that the process of policy formulation has suffered from several important problems. First, there was a lack of clarity about the role that public servants were supposed to play in a transitional context (agreement on the ultimate goals of reform was not achieved). Second, the process has suffered from discontinuity between the proposals advanced by expert groups (the "discourse community") and the ultimate outcomes of the negotiation process. One such example concerns Law no. 79, which changed quite radically several times during the time span of policy formulation process. A preliminary draft of the law had passed via several stages of reading in the State Legislature. However, when the time came for this law to be approved, experts discovered that the original project they worked on had changed significantly (Interviews 2010). Experts observe that various groups of public officials interfered into the process of policy formulation, thus undermining the ultimate goals of CSR.

Success in policy implementation process is usually identified with the outcomes that reform yields at the end of implementation stage, as well as with the ability of national governments to achieve policy goals formulated at the initial stage of political transformation. Polidano $(2001,1)$ argues that tactical choices in both the design and implementation of civil service reform can determine the ultimate outcomes of reform process. Meanwhile, researchers pay little attention to 
the interaction between tactical and strategic choices, and therefore explanations of why reforms fail or succeed turn out to be unhelpful.

In the case of Russia, there is a large area of uncertainty associated with the reform implementation process. First, it is difficult to identify the cases of success and failure, as reforms seem to have been formally implemented in nearly all areas of public service. Second, various reform initiatives (anti-corruption, merit-based recruitment, performance-based pay system and others) were launched interdependently as a way to improve the existing institutional framework. These measures did not yet produce any significant changes, and any assessment of outcomes they yield would require a longitudinal study of policy-making process.

The experts surveyed in my study adopted an overly pessimistic view of the outcomes of reform process. Some of them argued that none of the goals formulated by policy-makers in 2003-4 were practically achieved, whereas other interviewees expressed their concern and dissatisfaction with the quality and content of the law. The study clearly demonstrates that such norms of the Law no. 79 (2004) as article no. 11 ('The System of Ranks'), article no. 31 ('Organizational Restructuring of Civil Service Institutions'), article no. 33 ('Termination of Employment Regulations') and article no. 50 ('The System of Pay and Reimbursement') entailed multiple difficulties during the time of implementation process (Tikhomirov and Gorokhov 2009). Other norms, which covered the standards of conduct and conflict of interest regulations required major systematic improvements, and they were not implemented over the period of five to seven years since the start of the reform.

The lack of progress in CSR implementation could easily be explained by insufficient funding from the federal powers (the lack of political will to reform). However, it could also be linked to the post-Soviet legacy and the mismatch between the strategy of reform and the overwhelming nature of the regulations that were necessary to adopt in order to make it work (the impact of path-dependency upon the nature of policy-making system in Russia). Overall, the discussion of public administrative and civil service reforms in Russia justifies the need to disaggregate the key factors of the policymaking process. How committed was the top-level political elite to the process of CSR implementation in recent years? To what extent did the strategy of reform fit with the pre-existing institutional structure of the Russian state? Finally, what were the legacies of the post-Communist transformation and how did they influence reform progress? In what follows, this article will discuss these questions with the goal of testing the initial hypotheses of this study.

\section{Political Will and Priorities of the Russian Government ${ }^{6}$}

Since the fall of the Soviet Union, most post-Communist countries have struggled to reinvent their basic political institutions and to keep pace with the developments of the quickly changing world. The first generation of reforms in these societies included rapid systemic changes, such as privatization, macroeconomic stabilization, and liberalization of prices and trade. The second generation of reforms encompassed a variety of administrative measures aiming to reinforce the state's capacity and ability to govern.

Scholarly studies (Cameron 2007; Way and Levitsky 2010) suggest that very few postCommunist countries have managed to maintain stable democratic institutions. With the exception of the Baltic states, the Czech Republic, Hungary (until recently) and other countries

6. In this study, the will to reform is understood as a combination of leadership required for policy initiation process, and commitment to the reform process, based on policy continuity and legislative support. 
that have quickly become part of the European Union, the quality of the democratic process deteriorated quickly across the region. In Russia, the centralization stage replaced informal decentralization following the Yeltsin era. These developments informed the majority of political reforms in Putin's Russia, including PAR and CSR. More than anything else, they affected the style of the policy-making process in national and regional governments, leading to the adoption of hectic yet comprehensive reform strategies.

In Russia, the role of the central state in reforming the public administrative system was crucial. The Law no. 55, 'On Public Service System’ (2003), and Law no. 79, 'On State Civil Service in Russian Federation' (2004), were both initiated by the presidential administration, and they were both incorporated into a single strategy of comprehensive institutional transformation.

The approach taken by the Russian government toward reforms could be described as overly dynamic and comprehensive. First, experts observe that at the start of reform process, it seemed to be impossible to initiate reforms in one area of public service without reforming all the others. Second, in a country like Russia, much work had to be done to overcome the historical legacies reproduced within the context of the Post-Soviet transformation. The type of change initiated by the Russian government required a significant amount of "transformative capacity" on behalf of national and regional bureaucracies; therefore, it may be observed that approach toward reform relied on the contextually inappropriate prerequisites of the reform process.

To understand the role of political will in civil service reform in Russia, it is important to consider the flow of the government's priority-setting process during the time span of the reform, as well as the allocation of funds to the reform progress. Experts interviewed in my study observe that civil service reform attracted a greater amount of political support in the early 2000s than it did during the 1990s. The national government adopted over 30 normative acts dealing with the process of civil service reform implementation. ${ }^{7}$ However, in reality, CSR has never been placed as high on the agenda of the Russian government as other reform projects, such as public administrative, or state budget reforms. Starting from 2005, CSR initiatives have been toppled by the lack of consistency in the stage of implementation that was marked by the differential implementation progress in such areas as the process of rationalization, the development of job descriptions, standards of conduct and conflict of interest regulations. Furthermore, the funds allocated in support of the reform program have not been used efficiently, and as a result, reforms did not go through.

Another important issue to consider in explaining the role of political will to reform is the existing budget allocation process, and the way it changed during the last several years. Starting from 2003-2005, each annual budget in Russia has allocated a great portion of economic resources to foster the process of civil service reform implementation. For example, the Program of Civil Service Reform in 2003-2005, has funded the process in the amount of 539.1 million roubles (\$18 million), whereas the Program on Reform and Development of Civil Service in 2009-13 received the increased amount of 691 million roubles (\$23 million) $)^{8}$. Comparatively speaking, this funding appeared to be quite modest; however, in Russia, it could make a big difference. At least half of these funds went to a variety of research projects, whereas another half contributed to the actual processes of policy formulation and policy implementation.

7. The list includes: Presidential Decree «On Anti-Corruption Measures» no. 815 , (2008), Presidential Decree «On Commissions Dealing with the Standards of Conduct and Conflict of Interest Regulations» (2010), The Program on Civil Service Reform and Development (2009-2013), and others.

8. For more information, please see Federalnaya programma Reformrovania i Razvitia sistemy gosudarstvennoi sluzhby (2009-2013), Rossiiskaya Gazeta Federalny Vypusk, no. 4867, 13 March 2009. 
A great portion of the resources discussed above was used for scholarly research. Some experts observe that the money was 'wasted'-not because research was useless, but rather because it became irrelevant during the subsequent stages of the policy-making process. Interviewees assert that scholarly findings and suggestions have disappeared quickly, as soon as they reached the doors of conservative departments in State Duma. Draft laws have changed multiple times, depending on the group of interested actors who got access to the system of policy-making, which made the life of scholars particularly difficult.

Summing up, it would be reasonable to observe that the actual political leadership in Russia contributed significantly to the process of civil service reform initiation. The presidential administration was the main actor of policy-making process in 2004-5; it has also demonstrated commitment to reform progress by adopting a number of programs and normative acts that were crucial for the success of policy implementation process. However, a variety of factors that were crucial for a comprehensive reform project initiated by the federal government (such as the change in political goals and priorities over the time span of reform and the lack of transformative capacities), have made CSR somewhat irrelevant in the eyes of the top ranking officials. Formally, policy-makers remained committed toward the goals of the reform process; however, in practice, they were unable to reach multiple goals of CSR project in a short period of time, and focused on reforms that were manageable within the existing political constraints (such as Public Administration rationalization process).

The findings of my study confirm the idea of the first hypothesis of my research suggesting that both CSR and PAR have to be evaluated in a broader context of recent political transformations. The process of political centralization that started in the early 2000s imposed constraints upon the CSR reforms by dictating the top-level priority-setting process, and the very start of the new wave of reforms became possible with the change of the political environment during the early 2000s. However, several interviewees of my study confirmed that the goals of CSR (2004-5) did not fit appropriately within the framework of the ongoing political developments, and the reform was difficult to implement in the existing policy-making context. The goal of President Putin during his first term in office was to create an efficient, centralized and responsive administrative machine that would effectively support his initiatives, whereas the goals of the newly adopted Civil Service Law extended further into the area of rational organization of the post-Communist state apparatus (ethics, transparency, accountability). Consequently, the process of rationalization took place in a more dynamic fashion than the development of ethical standards dealing with issues of behavior, transparency and accountability in public administration.

The study does not confirm the idea that CSR was a politically motivated reform project, i.e., it may not have been driven by the intention to maintain the status quo, or by the willingness to appease various groups within the Russian society (at this moment, there is no evidence in support of this argument). Experts observe that in the period of 2000-13, there was genuine political will to modernize the Russian bureaucracy, which is evidenced by the surprising degree of policy continuity in the area of CSR. What remains unexplained, however, is the hectic nature of the reform funding process, and the dedication of the national government to the comprehensive design of the reforms. Some explanations to this conundrum will be offered in the section on the Strategy of Reform process in Russia. 


\section{Institutional design and the style of policy-making process}

To understand the relationship between political dynamics and the process of civil service reform implementation, one must take into consideration the type of institutional design developed in Russia over the last several decades. It was previously observed that the set of political reforms initiated by President Putin during his first years in office were aimed to strengthen the control of the federal authorities over the rest of society. These reforms included efforts at subordinating regional governors to the federal center, the reorganization of the Federal Council, reforming the principles of operation of political parties, etc.

Putin's quest for power produced both intended and unintended consequences for the nature of public choice institutions in Russia. One of the effects of these reforms was that the quality of democratic process significantly deteriorated, leading to the adoption of bad governance patterns. Another consequence was the lack of coherence in the existing policy-making system. ${ }^{9}$

Experts observe that in recent years, the system of public choice institutions was systemically skewed toward the executive. Needless to say, state bureaucrats acquired so much power and influence that they could easily dominate both the process of policy formulation and policy implementation. This process led to the lack of transparency and the narrowness of the circle of people who participated in the decision-making process.

The newly emerged institutional framework incorporated elements of both old and new Russia. In a nutshell, it was characterized by the following features: (1) the domination of the executive branch of power over the processes of policy formulation and policy implementation; (2) the diminishing accountability of political parties represented in the Russian Parliament to the public; and finally, (3) the lack of transparency combined with the narrowness of the circle of people who participate in the decision-making process.

Some experts (Krasnov 2003; Jackobson 2010) argue that the features of the existing institutional framework predetermined the failure of most political, social, and economic reforms in Russia. The domination of the executive narrowed down the circle of people involved in policy-making, whereas the lack of transparency and accountability impeded the process of reform implementation. Lev Jacobson (2010), the Vice Rector of the Higher School of Economics in Russia, argues that the Russian authorities adopted a "departmental," or "agencybased," approach toward administrative reforms. This choice profoundly affected the content of the new laws, as well as the pace of reform in general:

Given our relatively weak civil society and political parties, the main forum for representation and reconciliation of interests is provided by the executive authorities. Accordingly, government agencies and departments are the main actors involved in shaping the political agenda, as well as in its implementation. But the departmental (agency) approach to reforms is limited by definition. A radical agency project is a breakthrough in one relatively narrow area and is out of line with the general state of the public sector and public management. Such a breakthrough, first, is rarely successful on its own; second, it tends to produce unexpected effects in related areas; and third, it implies "bridge building” between

9. For more information on how these processes were coupled with the change of center-periphery relations in Russia please see DeBardeleben "Fiscal Federalism and How Russians Vote," Europe-Asia Studies, vol. 55, no. 3 (2003), pp. 339-363 (lead article). 
the sector under reform and its environment. Such "bridges" include the numerous amendments to laws, which make them internally inconsistent. (Jakobson 2010, 6)

The structure of basic political institutions in Russia stipulates the overly powerful role of the executive branch of power. One reason for this is the existing constitutional design (presidential system as opposed to the parliamentary system). However, the majority of the informal policymaking institutions appear to be grounded in the dynamics of political reforms, as well as the changing priorities of the Russian government. Given the hectic shifts of the policy agenda in recent years, some laws and programs (among them was the Law no.79 'On Civil Service Reform') emerged as a result of a rushed consensus among various policy actors with diverse interests and ideas regarding the future of public service in Russia. The process has suffered from the narrowness of the circle of people who make decisions; political commitments have changed over time, thus making it hard to fulfill some of the initial reform promises. Finally, the style of the policy-making process could be described as inconsistent and non-transparent.

In addition to the problems in the balance of power, the Russian executive system incorporates several other problematic areas. The government consists of a number of duplicating structures which do not seem to be working coherently on any policy initiative. The apparatus of the government, representing the right arm of President Putin, dominates the process of policy-making, and therefore it deprives other ministries with similar functions of any significant influence over reform content. All these processes, when combined, impede the effective coordination among ministries and agencies of the Russian Government, leading to the overall fragmentation of the policy-making process.

Summing up, this section of my study contributes to the second hypothesis of my research concerning the role of institutional design in the process of CSR implementation. The study suggests that the nature of institutional design developed in Russia during the last several years limits the circle of people participating in the process of policy formulation, and it splits the body of state bureaucrats in groups with conflicting interests and ideas (the most obvious split is between the higher-ranking and the lower-ranking bureaucrats, as well as between the groups belonging to different branches of power). An in-depth study of the nature of the body of civil servants in post-Communist Russia will be elaborated in the next phase of my research.

\section{Reform strategy}

It was observed earlier that the approach taken by the Russian authorities toward public sector reforms in the early 2000s was comprehensive by design, and it covered such areas as civil service, public administration, budget, taxation, and others. Civil service reform aimed at the profound change of the goals, rationales and principles of the existing system. Therefore, it relied on a deliberate reform strategy, with a selected choice of policy instruments.

Experts interviewed in my study observed that the strategy of civil service reform in Russia was marked by a radical break from the past of the early 1990s, as it aimed at redesigning the structure of the existing civil service system, with the goal of establishing policy implementation mechanisms for the newly adopted laws. However, in the early 2000s, the strategy of CSR has not been designed in a coherent manner, and therefore it incorporated several important problems. First, at the start of reform process, policy-makers approached comprehensive public administrative reform without considering the sequence of steps, as well as some of the existing temporal constraints of public policy change in a transitional context. (The Program of Reform in 
2001 outlined mostly generic policy objectives). Second, the policy instruments necessary for reform progress were not clearly elaborated. The Law "On Civil Service Reform” (2004) incorporated such legal constructs as "conflict of interest," "job pool," "administrative standing order," and so on. All of them were new to the existing institutional framework, and therefore the creation of policy implementation mechanisms consumed a great amount of policy-makers' time.

Another major mistake was that reformers maintained the old patterns of policy-making and did not actively involve civil servants in the process of policy formulation. Contrary to the expectations of the research community, by the year 2010 there was a large pool of civil servants in Russia who did not understand or share the goals of civil service reform. Thus instead of providing support for reformation, civil servants were not receptive to the goals of CSR and they more likely to distrust the federal government, acting on the assumptions derived from their previous experience with the nature of decision-making processes in Russia.

Critics describe the view of civil service reform among lower-level bureaucrats as "resistance from within," which emerged as a result of the dysfunctional reform communication strategy employed by the federal powers. One of the shortcomings of this strategy was that it did not pursue the goal of building alliances with the top-ranking and low-ranking public officials. Instead, it presented CSR as an ordinary change, one of many others they had to comply with.

Some of the obstacles to policy implementation process in Russia have emerged at the regional level. The enormous workload associated with parallel reform projects, as well as multiple conflicts over ideas, resources, and expertise in other areas of public sector created significant obstacles in CSR implementation process at the regional level. Thus, except for several outstanding regions such as Chuvashia, Kalmykia, St. Petersburg and Murmansk, the majority of territorial units in Russia did not take any interest in building comprehensive reform programs, and therefore they made little progress over the last several years (Interviews 2010; World Bank 2006, 7).

Overall, the findings of my study confirm the final hypothesis of this paper, suggesting that the content of CSR strategy (the scope of reform, the choice of policy instruments, as well as reform communication strategy) has also influenced the outcomes of civil service reform process. The overly comprehensive approach toward CSR, along with the choice of policy instruments were not appropriate within the existing policy-making process in Russia, and they have both relied on a path-dependent way of thinking about public policy change (viewing policy implementation as a top-down process, disregarding the scope, timing and sequencing issues in policy implementation process; believing that 'it is not possible to reform one area of public policy without a comprehensive reformation of public sector' ${ }^{10}$, prioritizing a 'control' version of policy implementation over the process of building alliances with public officials and others). On the other hand, it is obvious that policy-makers have tried to maintain some level of policy continuity by advancing a set of policy implementation measures, such as adopting the Program on Civil Service Reform and Development (2009-13). This tendency represented a notable break with the past of the early 1990s.

10. This phrase is derived from the Interview conducted by author with one of the participants of the policymaking process (Fall 2010). 


\section{Conclusion}

The case of Russia is interesting for a number of reasons. First, there is a question of leadership, or the willingness of the national political elite to improve the system of public administration. Second, there is a question of path-dependency and institutional transformation. Thirdly, there is a question of reform strategy, i.e. the scope of reform, the tactical and strategic choices made at the stage of policy formulation, and policy implementation process.

Results of my study support the main hypotheses of my research, suggesting that reform progress in a transitional context may be explained by a combination of such variables as political will, the strategy of reform and institutional legacies of the post-Communist transformation. First, the study suggests that political developments in the decades since the collapse of the Soviet Union informed the majority of public policy changes in Russia. Therefore, the success or failure of CSR has to be explored in a broader context of political transformation. The role of political will to reform in Russia was crucial at the initial stage of policy formulation process (early 2000s). However, the scope of ambition and political support significantly declined in recent years, which is evidenced by the structure of the government's priority-setting process, resource allocation problems and other indicators of the will to reform.

The strategy of the reform process in Russia influenced the outcomes of CSR in a less obvious way due to the fact that policy-makers did not fully consider the timing, the scope and sequencing issues of policy implementation strategy. The strategy of reform adopted in the early 2000s relied on a path-dependent way of thinking about the process of public policy change, which included the view of policy implementation as a top-down process, the tendency to disregard the prerequisites of comprehensive policy change and others.

Finally, the findings of my study suggest that the newly emerged institutional system in Russia informed the majority of public policy choices in recent years. The Russian system of public policy-making incorporated elements of both old and new institutional frameworks, where the traditions of secrecy, the domination of the executive branch, and other legacies of the past appear to be closely intertwined with an intention to create a viable, modern, highly effective civil service system. This model largely affected the flow of information, knowledge, and practices concerning the goals and outcomes of the reform process, therefore it holds answers to the question on where ideas are coming from, as well as why and how they get rejected or transformed into policy projects.

Overall, both reform design and reform implementation processes in Russia involve a standard, path-dependent approach toward the enactment of new legislation. Thus to achieve any significant change in post-communist public service, one must start by reconsidering the operating principles of the policy-making system. This process includes the transformation of both formal and informal institutions as well as their intended and unintended outcomes.

\section{ACKNOWLEDGEMENTS}

The author would like to thank Dr. Solomon, Dr. DeBardeleben, and Dr. Dutkiewicz for the advice and comments on this article. 


\section{REFERENCES}

\section{SECONDARY SOURCES}

Barzelay, Michael.2001. The new public management: improving research and policy dialogue. Berkeley, CA: University of California Press.

Beblavy, Miroslav. 2002. "Management of Civil Service Reform in Central Europe.” In Mastering Decentralization and Civil Service Reforms in Central and Eastern Europe. Edited by Gabor Peteri, 56-72. Budapest: Open Society Institute, 2002. Accessed April 16, 2013. http://www1.worldbank.org/publicsector/civilservice/june2004seminar/Chapter3.pdf

Brewer, Gene A. 2004. "Does Administrative Reform Improve Bureaucratic Performance? A Cross-Country Empirical Analysis.” Public Finance and Management 4 (3): 399-428.

Brym, Robert J., and Gimpelson, Vladimir. 2004. "The Size, Composition and Dynamics of the Russian State Bureaucracy in 1990s.” Slavic Review, 63 (1): 90-112.

Christensen Tom, and Lægreid Per. 2009. "Democracy and administrative policy: Contrasting elements of NPM and post-NPM.” Paper presented at EGPA Annual Conference 'The Public Service: Public Service Delivery in the Information Age’, Study Group VI: Governance of Public Sector Organizations, Malta, September 2-5, 2009. Accessed on 9 Jul. 2012. http://www.egpa2009.com/documents/psg6/Christensen\%20\&\%20Laegreid .pdf.

— 2007. Eds. Transcending New Public Management: The Transformation of Public Sector Reforms. Aldershot, UK: Ashgate.

Dmitriev, Mikhail. 2006. “Kuda Propal Zakon o Korruptsii?” Noavaya Gazeta 93, December 07. Accessed April 16, 2013. http://2006.novayagazeta.ru/nomer/2006/93n/n93n-s00.shtml

Faletti Tlia G. 2006. "Theory-Guided Process-Tracing in Comparative Politics: Something Old, Something New.” APSA-CP, Newsletter of the Organized Section in Comparative Politics of the American Political Science Association 17. 1 (Winter): 9-14.

Gaman-Golutvina, Oxana. 2008. "The Changing Role of the State and State Bureaucracy in the Context of Public Administration Reforms: Russian and Foreign Experience.” Journal of Communist Studies and Transition Politics 24 (1): 37-53.

Gudkov, Lev. 2010. Problema Elity v Sovremennoi Rossii - Razmyshlenia nad Rezultatami Sotsiologicheskogo Issledovania. Edited by Lev Gudkov, Boris Dubin, and Iurii Levada. Moscow: Fond Libaral'naia Missiia.

Higher School of Economics. 2004. "Reforma Gossluzhby v Rossii - Issledovanie Gosudarstvennykh i Munitsipalnykh Sluzhashikh“, Moscow: Higher School of Economics, 2004. Accessed Jul 9.2012. http://www.politanaliz.ru/articles_570.html.

Jakobson, Lev. 2010. “The Ambivalent Effect of Public Procurement Reform.” Paper presented at the VII World Congress (ICEES). 26-31 July, Stockholm.

_. 2011. "Public Management in Russia: Changes and Inertia.” International Public Management Journal, 4 (1): 27-48.

Johannsen, Lars, and Norgaard, Ole. 2001. "Governance and State Capacity in Post-Communist states.” Paper prepared for Workshop no. 2, 'Political transformation in Soviet successor states: the politics of CIS states in comparative and theoretical perspective.' ECPR Joint Sessions of Workshops, Institute of Political Studies, Grenoble. Accessed April 16, 2013. http://pure.au.dk/portal/en/publications/governance-and-state-capacity-in-postcommuniststates(17aa7590-1320-11db-bee9-02004c4f4f50).html.

Khan, Mohammad. 2001. Problems of Democracy: Administrative Reform and Corruption. BIISS Journal 22(1):1-24. 
Knill, Christoph. 1999. "Explaining Cross-National Variance in Administrative Reforms: Autonomous versus Instrumental Bureaucracies”, Journal of Public Policy, 19 (2): 113-139. Konov Alexey. [2006?]. "Public Service and Administrative Reform in Russia.” Report by the Working Group on Public Sector Quality. Accessed April 16. 2013. http://unpan1.un.org/intradoc/groups/public/documents/NISPAcee/UNPAN025557.pdf

Kotchegura, Alexander. 2008. Civil Service Reform in Post-Communist Countries. The Case of the Russian Federation and the Czech Republic. Leiden: Leiden University Press.

Levi, Margaret. 1997. “A Model, a Method, and a Map: Rational Choice in Comparative and Historical Analysis”, in Comparative Politics: Rationality, Culture, and Structure. Edited by Mark LichBach and Alan Zucherman. Cambridge University Press.

Meyer-Sahling, Jan-Henrik. 2009. "Sustainability of Civil Service Reforms in Central and Eastern Europe Five Years After EU Accession”, Sigma Papers, No. 44, OECD Publishing. Accessed April 16, 2013. http://www.oecd-ilibrary.org/docserver/download/5kml60pvjmbq.pdf? expires=1366153532\&id=id\&accname=guest \&checksum=AC6282848E27BF0CF002230F4 5713193 http://dx.doi.org/10.1787/5kml60pvjmbq-en.

Mendras, Maria. 2002. "The State is Weak, Administrations are Strong. Assessing the Functionality of Bureaucracies in Russia." Paper presented at the Honesty and Trust Project workshop Collegium, Budapest, 13-14 December:1-25. Accessed April 16, 2013. www.colbud.hu/honesty-trust/mendras/pub02.doc.

Mazmanian, Daniel, and Sabatier, Paul. 1981. Effective Policy Implementation. Lexington Books, Lexington, Mass: D.C. Health.

Nunberg, Barbara. 1999. The State After Communism: Administrative Transitions in Central and Eastern Europe. Washington, DC: The World Bank.

Oleinik, Anton. 2009, ed. Reforming the State without Changing the Model of Power? On Administrative Reform in Post-Socialist Countries. London and New York: Routledge. 2009.

Parison, Nill. 2000. "Russia: Public Administration Reform, Issues and Options.” The World Bank Conference on Post-Election Strategy, Moscow, April 5-7. Accessed April 16. 2013. http://www.imf.org/external/pubs/ft/seminar/2000/invest/pdf/parison.pdf

Pierson, Paul. 2000. “Increasing Returns, Path Dependence, and the Study of Politics.” The American Political Science Review 94(2): 251-267.

Polidano, Charles. 2001. "Why Civil Service Reforms Fail?” IDPM Public Policy and Management Working Paper no.16. Accessed July 122012. http://www.gsdrc.org/go/display\&type=Document\&id=447.

Ross, Cameron. 2003. "Putin’s Federal Reforms and the Consolidation of Federalism in Russia: One new Step Forward, Two Steps Back.” Communist and Post-Communist Studies, 36: 2947.

Shabrov, Oleg. 2005. "Reforma Gosudarstvennoi Sluzhby: Otkrytost ili Effektivnost?” Sotsiologia Vlasti, 6. Accessed July 9, 2012. http://shabrov.info/Statji/transpar.htm

Smorgunov, Leonid. 2008. “Administrativnaya Reforma v Regionakh - Mesto IKT v Strategiiakh Razvitiia.” Sankt-Peterburgskii Gosudarstvenny Universitet. Internet $i$ Sovremennie Obshestvo, IMS. Accessed on July 9, 2012. http://www.ict.edu.ru/vconf/files/10367.pdf

Solomon, Peter. 2008. “Law in Public Administration: How Russia Differs.” Journal of Communist Studies and Transition Politics 24 (1): 115-135. 
Temmes, Markku. 2004. “The Governance Discourse in Three Countries, A Comparison of Administrative Reform Activities in Finland, Estonia and Russia.” The Paper Presented at the $12^{\text {th }}$ NISPAcee Annual Conference "Central and Eastern European Countries Inside and Outside the European Union: Avoiding a New Divide.” Vilnus, Lithuania, May 13-15. Accessed on April 16, 2013. http://unpan1.un.org/intradoc/groups/public/documents/nispacee/unpan018512.pdf

Tikhomirov, Iurii, and Gorokhov Dmitrii. 2009. "Legal Monitoring of the Federal Law no. 79 'On State Civil Service in the Russian Federation.” In Legal Monitoring - Theoretical and Empirical Handbook. Edited by Iurii Tikhomirov and Dmitrii Gorokhov. Moscow: Jurisprudence, Institute of Legislation and Comparative Law Under the Government of the Russian Federation, 287-320.

World Bank, 2006. "Institutional Reform in Russia: Moving From Design to Implementation in a Multi-Level Governance Context. Study”. World Bank Report no. 35576-RU (June). Accessed July 9, 2012. http://siteresources.worldbank.org/INTRUSSIANFEDERATION/ Resources/Institutionaleng.pdf

\section{KEY PRIMARY SOURCES}

Federal'naia programma "Reformrovania i razvitie sistemy gosudarstvennoi sluzhby Rossiiskoi Federatsii” (2009-2013), (Federal Program “On Reform and Development of Civil Service System in Russia”) Rossiiskaia Gazeta Federal'nyi Vypusk, no. 4867, March 13, 2009.

Federal'nyi zakon Rossiiskoi Federatsii “O gosudarstvennoi grazhdanskoi sluzhbe Rossiiskoi Federatsii” (The Federal Law “On State Civil Service of the Russian Federation”, no.79, Rossiiskaya Gazeta Federal’nyi Vypusk, no. 3539, July 31, 2004.

Federal'nyi zakon Rossiiskoi Federatsii “Ob osnovakh gosudarstvennoi grazhdanskoi sluzhby” (The Federal Law "On the Basic Principles of State Civil Service”, no. 119, Rossiiskaia Gazeta, August 5, 1995. http://www.rg.ru/oficial/doc/federal_zak/fed5.html.

Goncharov V. (Former) Head of the Legal Department in the Moscow city Government (Pravitel’stvo Moskvy); interview by author, Russia, Moscow, 2010.

Klimenko A. (Vice-Chancellor of the National Research Institute "Higher School of Economics”); interview by author, Russia, Moscow, October 2010.

Kudiukin P. (Professor of the National Research Institute "Higher School of Economics”); interview by author, Russia, Moscow, 2010.

Klishch, N. (Lecturer at the National Research Institute "Higher School of Economics”); interview by author, Russia, Moscow, 2010.

Interviews with experts and public officials (anonymous), conducted by author, OctoberNovember 2010.

Proekt Kontseprsii Administrativnoi Reformy. 2003. Indem Foundation, March. Accessed April 10, 2012. http://www.anti-corr.ru/rutxt/2003/admin_reform/index.htm

Ukaz Presidenta Rosiiskoi Federatsii “O reforme gosudarstvennoi sluzhby v Rossiiskoi Federatsii” (Decree of the President of the Russian Federation, no.1336, November 192002 “On Reform of the Public Service of the Russian Federation 2003-2005”). Rossiiskaia Gazeta, 27 June, 2004. Accessed April 16, 2013. http://www.rg.ru/2002/11/23/gosslujbadok.html.

Ukaz Presidenta Rosiiskoi Federatsii 'Reformirovanie i razvitie gosudarstvennoi grazhdanskoi sluzhby' (Decree of the President of the Russian Federation, no.261 of March 10, 2009 “On Federal Program "Reformation and Development of the State Civil Service of the Russian Federation 2009-2013”). Rossiiskaia Gazeta, 11 March, 2009. Accessed April 16, 2013. http://www.rg.ru/2009/03/11/ukaz-dok.html. 
Correct citation: Inkina, Svetlana. 2013. "Civil Service Reform in Transition: A Case Study of Russia.” Review of European and Russian Affairs 8 (1): 1-16.

Published by the Centre for European Studies at Carleton University, Ottawa, Canada. Available online at: www.carleton.ca/rera/

RERA is an electronic academic peer-reviewed journal that publishes graduate, post-graduate, and young scholarly works. Topics relate to the European Union, its Member States, the former Soviet Union, and Central and Eastern Europe. The journal is a joint project supported by the Canada-Europe Transatlantic Dialogue-a cross-Canada research network supported by the Social Sciences and Humanities Research Council of Canada (SSHRC)—along with the Institute of European, Russian and Eurasian Studies (Carleton University) and its associated research unit, the Centre for European Studies.

RERA aims to provide an accessible forum for research, to promote high standards of research and scholarship, and to foster communication among young scholars.

\section{Contact:}

Carleton University

The Centre for European Studies

1103 Dunton Tower

1125 Colonel By Drive

Ottawa, ON

K1S 5B6

Canada

Tel: +01 613 520-2600 ext. 1179; E-mail: rera-journal@carleton.ca

\section{Creative Commons License}

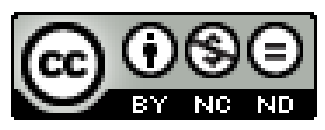

http://creativecommons.org/licenses/by-nc-nd/3.0/

This Working Paper is licensed under a Creative Commons Attribution-Non-CommercialNo Derivs 3.0 Unported License (CC BY-NC-ND 3.0).

Articles appearing in this publication may be freely quoted and reproduced provided the source is acknowledged. No use of this publication may be made for resale or other commercial purposes.

ISSN: 1718-4835

(C) 2013 The Author(s) 